\author{
ILONA RADZIWON \\ Uniwersytet w Białymstoku \\ radziwonilona@o2.pl
}

\title{
Rozwiązanie umowy o pracę z powodu ciężkiego naruszenia podstawowych obowiązków wobec pracownika
}

\author{
Termination of employment contract by the employee without the notice due to the fault \\ employer
}

Streszczenie. Artykuł przedstawia zagadnienie rozwiązania umowy o pracę przez pracownika bez wypowiedzenia z winy pracodawcy. Analizie poddano pojęcie ciężkiego naruszenia podstawowych obowiązków przez pracodawcę jako przesłankę do rozwiązania umowy o pracę przez pracownika bez wypowiedzenia. Celem niniejszego opracowania jest także wskazanie formy i konsekwencji oświadczenia woli pracownika prowadzących do rozwiązania stosunku pracy oraz kwestii odszkodowania przysługującego mu z tego tytułu. Artykuł został wzbogacony o aktualne stanowisko doktryny i orzecznictwa w sprawach spornych z omawianego problemu.

Słowa kluczowe: rozwiązanie stosunku pracy bez wypowiedzenia $\mathrm{z}$ winy pracodawcy; ciężkie naruszenie obowiązków pracodawcy; obowiązki pracodawcy; odszkodowanie przysługujące pracownikowi; skutki rozwiązania umowy o pracę bez wypowiedzenia przez pracownika.

Summary. The article presents termination of employment contract by the employee without the notice due to the fault employer. In this text is analyzing the concept severe infringement of employer's obligations as a premise for termination of employment by the employee without notice. The purpose of this article is an indication of the form and consequences of the statement of intent employee which conduct to terminate of employment contract and affair of compensation payable to him in this respect. Moreover the article has been enhanced with the current line of the doctrine and jurisprudence in contentious cases of this problem.

Keywords: termination of employment without notice by employee; severe infringement of employer's obligations; compensation for employee; consequences of termination of employment without notice by employee.

\section{Wstęp}

Kodeks pracy w art. 55 zawiera katalog przyczyn uprawniających pracownika do rozwiązania stosunku pracy bez wypowiedzenia. Oznacza to, że w razie zaistnienia innych okoliczności niż przewidziane $\mathrm{w}$ niniejszym przepisie (np. naruszenia prywatności pracownika przez innego pracodawcę działającego na terenie zakładu pracy) pracownik nie ma prawa do niezwłocznego rozwiązania umownego stosunku pracy, a jego ewentualne niestawienie się do pracy może zostać uznane przez pracodawcę za ciężkie naruszenie podstawowych obowiązków pracowniczych z art. 52 §1 pkt 1 k.p. 
Zgodnie $\mathrm{z}$ kodeksem pracy rozwiązanie stosunku pracy bez wypowiedzenia przez pracownika z winy pracodawcy może nastąpić, gdy:

1) zostanie wydane orzeczenie lekarskie stwierdzające szkodliwy wpływ wykonywanej pracy na zdrowie pracownika, a pracodawca nie przeniesie go w terminie wskazanym w orzeczeniu lekarskim do innej pracy, odpowiedniej ze względu na stan jego zdrowia i kwalifikacje zawodowe (art. $55 \S 1$ ), oraz

2) pracodawca naruszy w sposób ciężki swoje obowiązki (art. $55 \S 1^{1}$ ).

\section{Pojęcie ciężkiego naruszenia podstawowych obowiązków wobec pracownika}

\subsection{Ciężkie naruszenie obowiązków}

Kluczowe dla dalszej interpretacji przepisów prawnych jest ustalenie zakresu pojęcia „ciężkie naruszenie przez pracodawcę podstawowych obowiązków wobec pracownika". Otóż owo naruszenie powstaje, gdy pracodawca umyślnie lub poprzez rażące niedbalstwo narusza swoje obowiązki dotyczące pracownika. W praktyce w pierwszej kolejności należy rozstrzygnąć, czy pracodawca naruszył podstawowy obowiązek wobec pracownika. W przypadku uzyskania odpowiedzi twierdzącej, wypada rozważyć, czy owo naruszenie miało charakter ciężki ${ }^{1}$.

W literaturze przyjmuje się, że do tego, aby doszło do ciężkiego naruszenia, niezbędne jest pojawienie się winy pracodawcy. Naruszenie to nie musi polegać jedynie na wyrządzeniu szkody materialnej. Chronionym interesem pracownika jest przykładowo jego bezpieczeństwo, zdrowie, godność lub prawo do wypoczynku. Oprócz tego należy zaznaczyć, że interesy pracownika i pracodawcy mogą się różnić w zależności od czynników takich, jak: wiek, płeć, stan zdrowia, itp. ${ }^{2}$. W literaturze istnieje raczej odosobniony pogląd, iż ciężkie naruszenie obowiązków przez pracodawcę może wystąpić bez winy. M. Piankowski twierdzi, że pominięcie słowa „wina” w art. $55 \S 1^{1}$ k.p. nie jest przypadkowe, lecz wynika z dążenia ustawodawcy do odmiennego ukształtowania reguł zastosowania tego przepisu w stosunku do art. 52 k.p. ${ }^{3}$. Z kolei A. Sobczyk odrzuca powyższe stanowisko, twierdząc, iż nie jest uzasadnione odwoływanie się do kwestii ryzyka gospodarczego w celu znalezienia podstawy dla odrzucenia winy jako przesłanki prawidłowego zastosowania art. $55 \S 1^{1}$ k.p. Zdaniem tego Autora, z faktu, iż pracodawca nie jest w stanie z powodów niezawinionych wypełniać

\footnotetext{
${ }^{1}$ Wyrok SN z dnia 27 lipca 2013 r., I PK 53/12, OSNP 2013, nr 15-16, poz. 173.

${ }^{2}$ W. Sanetra, Kilka uwag o pojęciu odpowiedzialności w prawie pracy, „Praca i Zabezpieczenie Społeczne” 2007, nr 11, s. 10-12.

${ }^{3}$ M. Piankowski, Niezwłoczne rozwiąanie stosunku pracy przez pracownika, w: Prawo pracy po zmianach, red. K. Rączka, Warszawa 1997, s. 205.
} 
swoich obowiązków wobec pracownika, nie wynika to, że pracownik traci swoje roszczenia. Ryzyko ekonomiczne polegałoby wówczas na związaniu praw pracownika z sytuacją ekonomiczną pracodawcy. Należy podkreślić, że dopuszczalność zastosowania konkretnego trybu rozwiązania stosunku pracy nie ma z tym związku ${ }^{4}$.

Odmienny pogląd wyraził L. Florek, którego zdaniem wina pracodawcy nie może być ujmowana $\mathrm{w}$ taki sam sposób jak wina pracownika, o której mowa w art. 52 k.p. Odpowiedzialność pracodawcy kształtuje się bowiem nie tylko na zasadzie ryzyka, ale również na zasadzie winy ${ }^{5}$. Jak podkreśla A. Sobczyk, definiowanie pojęcia „ciężkie naruszenie", jako obejmującego swą treścią kwalifikowaną postać winy, ma w polskim prawie pracy już kilkadziesiąt lat. Ustawodawca mógł użyć innej formuły na wyrażenie treści, zgodnie z którą stopień winy pracodawcy nie miałby jakiegokolwiek znaczenia, np. istotne naruszenie albo poważne naruszenie ${ }^{6}$. Z kolei Sąd Najwyższy stoi na stanowisku, że wina umyślna lub rażące niedbalstwo jest wymaganą przesłanką uzasadnionego rozwiązania umowy o pracę w tym trybie ${ }^{7}$.

\subsection{Podstawowe obowiązki pracodawcy}

Nie sposób wymienić wszystkich zachowań pracodawcy stanowiących ciężkie naruszenie obowiązku wobec pracownika. Do najważniejszych z nich K. Baran ${ }^{8}$ i orzecznictwo zaliczają zachowania naruszające w sposób ciężki:

1) godność pracownika ${ }^{9}$ lub sferę jego prywatności ${ }^{10}$ (wynikające $\mathrm{z}$ art. $11^{1}$ k.p.) :

a) bezzasadne publiczne przypisanie pracownikowi dokonania przestępstwa lub czynu hańbiącego,

b) nieuzasadnione użycie przemocy fizycznej bądź psychicznej wobec pracownika,

c) bezprawny i tajny monitoring miejsca świadczenia pracy bądź innych miejsc użytkowanych przez pracownika w celach osobistych (np. szatni) ${ }^{11}$,

\footnotetext{
${ }^{4}$ A. Sobczyk, Rozwiąanie umowy o pracę bez wypowiedzenia, Warszawa 2010, s. 92-93.

${ }^{5}$ L. Florek, Komentarz. Kodeks pracy, Warszawa 2005, s. 431.

${ }^{6}$ A. Sobczyk, Rozwiąanie..., s. 94.

${ }^{7}$ Wyrok SN z dnia 6 marca 2008 r., II PK 185/07, OSNP 2009, z. 13-14, poz. 170; wyrok SN z dnia 4 kwietnia 2000 r., I PKN 516/99, OSNP 2001, z. 11, poz. 601.

${ }^{8}$ K.W. Baran, Kodeks pracy. Komentarz, Warszawa 2012, s. 392- 395.

${ }^{9}$ Wyrok SN z dnia 8 października 2009 r., II PK 114/09, LEX nr 558297, t. 2 i 3; wyrok SN z dnia 6 marca 2008 r., II PK 185/07, OSNP 2009, nr 13-14, poz. 170.

${ }^{10}$ M. Wujczyk, Prawo pracownika do ochrony prywatności, Warszawa 2012, s. 148 i n.; T. Liszcz, Ochrona prywatności pracownika w relacjach z pracodawca, ,,Monitor Prawa Pracy” 2007, nr 1, s. 11.

11 D. Dörre- Nowak, Monitoring $w$ miejscu pracy a prawo do prywatności, „Praca i Zabezpieczenie Społeczne” 2004, nr 9, s. 8; Z. Góral, Kontrola pracownika a zasada ochrony jego godności i innych dóbr osobistych zagadnienia wybrane, w: Kontrola pracownika. Możliwości techniczne i dylematy prawne, red. Z. Góral, Warszawa 2010, s. 45 i n.
} 
d) powierzenie byłemu wiceprezesowi spółki pracy fizycznej na hali produkcyjnej nieodpowiadającej jego kwalifikacjom ${ }^{12}$,

e) odwetowe sankcje pracodawcy zmierzające do zdyskredytowania pracownika, naruszające jego dobra osobiste ${ }^{13}$,

f) opublikowanie w Internecie albo w innych mediach elektronicznych imiennej listy płac, z wyliczeniem zarobków konkretnego pracownika bez jego zgody,

g) bezprawne przeglądanie poczty elektronicznej pracownika bądź innych należących do niego urządzeń teleinformatycznych,

h) nękanie bądź zastraszanie pracownika lub zaniechanie podjęcia działań antymobbingowych,

i) molestowanie lub molestowanie seksualne pracownika,

j) nakazanie pracownikowi wykonania szczepień zagrażających jego zdrowiu,

k) przekazanie danych osobowych innym podmiotom bez zgody pracownika,

2) zasady równego traktowania pracowników (zakaz dyskryminacji art. $11^{2}, 11^{3}$ k.p.):

a) uporczywe poniżanie bądź ośmieszanie pracownika ze względu na pochodzenie etniczne lub orientację seksualną,

b) nieuzasadnione permanentne pomijanie w awansach lub delegowaniu na szkolenia zawodowe,

c) nieuzasadnione niekorzystne ukształtowanie warunków zatrudnienia na tle pracowniczej grupy odniesienia,

d) szykanowanie pracownika ze względu na przekonania polityczne lub przynależność związkową,

e) ustanowienie szczególnie uciążliwych obowiązków pracowniczych ze względu na osobisty konflikt ze współpracownikami,

3) prawo do wynagrodzenia (art. 13 k.p.):

a) zaniechanie wypłaty $^{14}$ należnego pracownikowi wynagrodzenia ${ }^{15}$, chyba że dotyczy to świadczeń o małej wartości bądź o charakterze fakultatywnym ${ }^{16}$,

b) opóźnienie wypłaty wynagrodzenia ${ }^{17}$, jeżeli jest ono w wymiarze temporalnym znaczne lub skutkuje dla pracownika poważnymi następstwami,

\footnotetext{
${ }_{12}^{12}$ Wyrok SN z dnia 21 lutego 2008 r., II PK 171/07, OSNP 2009, nr 9-10, poz. 118.

${ }^{13}$ Wyrok SN z dnia 7 grudnia 2006 r., I PK 123/06, OSNP 2008, nr 1-2, poz. 14, t. 3.

${ }^{14}$ A. Musiała, Niewypłacenie wynagrodzenia ciężkim naruszeniem podstawowych obowiazków pracodawcy, „Monitor Prawa Pracy” 2008, nr 4, s. 217-219.

${ }_{15}$ Wyroki SN: z dnia 5 lipca 2005 r., I PK 276/04, Wokanda 2006, nr 2, s. 23; z dnia 8 sierpnia 2006 r., I PK 54/06, OSNP 2007, nr 15-16, poz. 219.

${ }^{16}$ Wyrok SN z dnia 5 czerwca 2007 r., III PK 17/07, LEX nr 551138, t. 3; wyrok SN z dnia 10 kwietnia 2008 r., III PK 88/07, LEX nr 469173, t. 1.
} 
c) wypłata wynagrodzenia na inny rachunek bankowy niż wskazany przez pracownika, wskutek czego utracił on, chociaż przejściowo, możliwość dysponowania środkami finansowymi,

d) uporczywe dokonywanie potrąceń z wynagrodzenia ponad limity przewidziane ustawą albo bez zgody pracownika,

e) błędne obliczenie wysokości należnego pracownikowi wynagrodzenia, jeżeli dotyczy znacznych kwot albo zostało dokonane umyślnie,

f) spełnienie wynagrodzenia $\mathrm{w}$ formie rzeczowej, jeżeli przepisy nie przewidują takiej możliwości,

g) odmowa podniesienia wysokości wynagrodzenia do poziomu płacy minimalnej określonej ustawą lub określenie płacy na poziomie poniżej płacy minimalnej,

4) prawo do wypoczynku (wynikające z art. 14 k.p.):

a) złośliwa odmowa udzielenia urlopu wypoczynkowego w ustawowym terminie,

b) bezpodstawne obniżenie wymiaru należnego urlopu,

c) nieuzasadnione obiektywnymi okolicznościami odwołanie z urlopu, pociągające dla pracownika poważne skutki finansowe bądź osobiste,

d) uporczywe naruszanie prawa pracownika do nieprzerwanego odpoczynku dobowego lub tygodniowego,

e) permanentne i nieuzasadnione potrzebami zakładu pracy przekraczanie obowiązujących pracownika norm czasu pracy w godzinach nadliczbowych,

f) nieuzasadniona bądź oczywiście bezprawna odmowa udzielenia urlopu dla poratowania zdrowia,

5) prawo do bezpiecznych i higienicznych warunków pracy (art. 15 k.p.):

a) nakazanie pracownikowi świadczenia pracy $\mathrm{w}$ warunkach bezpośrednio zagrażających życiu lub zdrowiu,

b) polecenie kobiecie świadczenia pracy w warunkach szczególnie uciążliwych i szkodliwych dla zdrowia,

c) nakazanie kobiecie w ciąży świadczenia pracy w godzinach nadliczbowych albo w porze nocnej,

d) uporczywa odmowa dostarczania pracownikom posiłków i napojów regeneracyjnych,

6) inne obowiązki wobec pracownika, głównie o charakterze formalnym:

\footnotetext{
${ }^{17}$ Wyrok SN z dnia 10 kwietnia 2008 r., III PK 88/07, LEX nr 469173.
} 
a) zaniechanie prowadzenia dokumentacji pracowniczej lub jej zniszczenie albo zagubienie,

b) stosowanie rażąco nieobiektywnych ocen pracy świadczonej przez pracownika,

c) nakłanianie do donosicielstwa lub innych działań nieetycznych,

d) zastosowanie wobec pracownika kary porządkowej nieprzewidzianej w ustawie albo rażące naruszenie procedury (np. odmowa wysłuchania pracownika).

Moim zdaniem jednym z najważniejszych obowiązków pracodawcy jest wypłata wynagrodzenia pracownikowi za świadczoną przez niego pracę. Niewypłacenie przez pracodawcę wynagrodzenia za pracę stanowi podstawę do rozwiązania stosunku pracy bez wypowiedzenia przez pracownika z winy pracodawcy. Dlatego też kwestia ta zostanie szerzej omówiona.

\section{Naruszenie przez pracodawcę obowiązków związanych $\mathrm{z}$ wyplatą wynagrodzenia}

Nie ma wątpliwości, że fundamentalnym obowiązkiem pracodawcy jest terminowa wypłata pracownikowi wynagrodzenia za świadczoną przez niego pracę. Stanowi o tym art. 94 pkt 5 k.p. Obowiązek pracodawcy wypłaty wynagrodzenia ma charakter bezwzględny, co oznacza, że jest niezależny od rezultatu pracy pracownika lub od osiągnięcia celów, dla których stosunek pracy nawiązano. Zdaniem U. Torbus bezwzględny charakter omawianego obowiązku potwierdza zakaz zrzeczenia się prawa do wynagrodzenia oraz jego przeniesienia na inną osobę (art. 84 k.p.). Zatem niewypłacenie wynagrodzenia stanowi naruszenie podstawowego obowiązku pracodawcy wobec pracownika ${ }^{18}$. Zarówno doktryna, jak i orzecznictwo, zgodnie wyrażają pogląd, iż pracodawca niewypłacający pracownikowi wynagrodzenia w terminie narusza swój podstawowy obowiązek z winy umyślnej, nawet jeśli z przyczyn niezawinionych nie uzyskał funduszy na wynagrodzenie ${ }^{19}$. Zdaniem A. Sobczyka nieprawidłowe jest odnoszenie zawinienia pracodawcy do kwestii uzyskania przez niego środków finansowych właśnie na wypłatę wynagrodzenia dla pracowników, bowiem to na pracodawcy ciąży ryzyko prowadzonej działalności. Nie można zatem przekładać tego ryzyka na pracownika, a sam element zawinienia powinien być tylko odnoszony do obowiązku terminowego wypłacania wynagrodzenia ${ }^{20}$. Pojawia się tu element winy pracodawcy, który obejmuje winę umyślną lub rażące niedbalstwo. Pracodawca musi dążyć do niedokonania wypłaty wynagrodzenia w terminie (zamiar bezpośredni), albo przewidując możliwość

\footnotetext{
${ }^{18}$ U. Torbus, Glosa do wyroku SN z dnia 24 października 2013 r., II PK 25/13, GSP- Prz. Orz. 2014, nr 3, s. 6778.

${ }^{19}$ Wyrok SN z dnia 4 kwietnia 2000 r., I PKN 516/99, OSNP 2001, z. 16, poz. 51.

${ }^{20}$ A. Sobczyk, Rozwiazanie..., s. 101.
} 
niedokonania terminowej wypłaty wynagrodzenia godzić się na to (zamiar ewentualny) albo nieterminowa wypłata wynagrodzenia musi być wynikiem niedochowania należytej staranności $\mathrm{w}$ realizacji tego podstawowego obowiązku pracodawcy $\mathrm{w}$ stopniu rażącym. $\mathrm{Z}$ powyższego wynika, iż nie ma ciężkiego naruszenia obowiązków pracodawcy w przypadku, gdy jest ono niezawinione lub zawinione w niewielkim stopniu ${ }^{21}$.

Kodeks pracy w art. $282 \S 1$ pkt 1 reguluje kwestię odpowiedzialności pracodawcy za nieterminowe wypłacenie wynagrodzenia. Mianowicie, za to pracodawcy grozi kara grzywny od 1000 zł do 30000 zł. Zdaniem Sądu Najwyższego istotne znaczenie przy wymierzaniu kary i ustaleniu zawinienia pracodawcy ma ustalenie, że nie istniała przyczyna, która należycie usprawiedliwiałaby niewypłacenie należnych pracownikom świadczeń pieniężnych. Jedną z przyczyn może być sytuacja, w której pracodawca ze względu na niestabilne warunki finansowe nie jest w stanie zapewnić regularnej wypłaty zobowiązań ${ }^{22}$.

Zdaniem U. Torbus istotne jest odróżnienie niewypłacenia pracownikowi wynagrodzenia w całości od niewypłacenia części wynagrodzenia. Zdaniem Autorki niewypłacenie całości wynagrodzenia zwykle stanowi realne zagrożenie interesów pracownika, z wyjątkiem sytuacji, gdy opóźnienie ma charakter kilkudniowy. Natomiast w odniesieniu do niewypłacania części wynagrodzenia istotne znaczenie ma kwestia proporcji niewypłaconego składnika wynagrodzenia do reszty wypłaty, powtarzalność i uporczywość zachowania pracodawcy ${ }^{23}$ lub sporny charakter danego niewypłaconego składnika wynagrodzenia. Sporadyczne niewypłacenie drobnej części wynagrodzenia (w odniesieniu do całego wynagrodzenia) nie może zostać zakwalifikowane jako ciężkie naruszenie obowiązków przez pracodawcę ${ }^{24}$.

Po tych rozważaniach można stwierdzić, iż niewypłacenie $\mathrm{w}$ terminie całości wynagrodzenia stanowi ciężkie naruszenie obowiązków pracodawcy, co uzasadnia rozwiązanie umowy o pracę bez wypowiedzenia w trybie art. $55 \S 1^{1}$ k.p. Oznacza to, że pracownikowi w takim przypadku przysługuje odszkodowanie w wysokości wynagrodzenia za okres wypowiedzenia, a jeżeli umowa o pracę została zawarta na czas określony lub na czas wykonania określonej pracy - w wysokości wynagrodzenia za okres 2 tygodni.

Podobnie dzieje się, gdy pracodawca nie wypłaca w terminie części wynagrodzenia. Judykatura zgodnie twierdzi, że takie zachowanie stanowi ciężkie naruszenie obowiązku

\footnotetext{
${ }^{21}$ Wyrok SN z dnia 6 marca 2008 r., II PK 185/07, OSNP 2009, z. 13-14, poz.170; wyrok SN z dnia 4 kwietnia 2000 r., OSNP 2001, z. 16, poz. 51 oraz A. Sobczyk, Rozwiazanie..., s. 101.

${ }^{22}$ Wyrok SN z dnia 23 września 2009 r., IV KK 66/09, LEX nr 524064.

${ }^{23}$ Wyrok SN z dnia 8 lipca 2009 r., I BP 5/09, OSNP 2011, nr 5-6, poz. 69.

${ }^{24}$ U. Torbus, Glosa ..., s. 67-78.
} 
pracodawcy, co wynika z art. 94 pkt 5 k.p. Naruszenie to powinno jednak podlegać wnikliwej ocenie w zakresie stopnia winy pracodawcy (wina umyślna, rażące niedbalstwo), która przy niewypłaceniu całości wynagrodzenia $\mathrm{z}$ reguły jest oczywista ${ }^{25}$. W przypadku, gdy spór o wypłatę wynagrodzenia dotyczy jakiegoś jego składnika regulowanego niejasnymi regułami prawa pracy, wówczas pracodawcy niewypłacającemu tego składnika nie można zarzucić naruszenia jego obowiązku. Natomiast, gdy pracodawca świadomie nie wypłaca wspomnianego składnika wynagrodzenia, dopuszcza się ciężkiego naruszenia obowiązków ${ }^{26}$. Jak twierdzi A. Sobczyk, kontekst sytuacyjny omawianych orzeczeń Sądu Najwyższego miał znaczenie dla kwalifikacji zachowania pracodawcy. Ponadto wina pracodawcy w przypadku niewypłacenia całego wynagrodzenia jest co do zasady umyślna ${ }^{27}$. Przychylam się do tezy prezentowanej przez A. Sobczyka.

\section{Termin i oświadczenie woli pracownika o rozwiązaniu umowy o pracę bez wypowiedzenia}

Na gruncie omawianego zagadnienia istotne jest określenie terminu do skorzystania przez pracownika $\mathrm{z}$ uprawnienia do rozwiązania umowy o pracę $\mathrm{w}$ razie niewypłacenia mu wynagrodzenia za pracę. Termin realizacji uprawnienia pracownika do rozwiązania umowy bez wypowiedzenia z winy pracodawcy nie wynika expressis verbis z art. 55 k.p., lecz z art. $52 \S 2$ k.p. Pracownik może zatem rozwiązać stosunek pracy w okresie miesiąca od momentu, w którym dowiedział się o zdarzeniu. Wiadomość o tym zdarzeniu powinna być wiarygodna, zaś pracownik musi otrzymać ją osobiście. Wówczas jest to przyczyna uzasadniająca rozwiązanie stosunku pracy bez wypowiedzenia. Należy podkreślić, iż termin rozpoczyna bieg od dnia, w którym wynagrodzenie miało być wypłacone. Zgodnie z zasadą zawartą w art. $85 \S 1$ k.p., wynagrodzenie wypłacane jest raz w miesiącu w stałym i w ustalonym z góry terminie. Miejsce, termin i częstotliwość wypłaty wynagrodzenia ustalane są w układzie zbiorowym lub regulaminie pracy, jeśli pracodawca nie jest objęty układem zbiorowym i zatrudnia powyżej 20 pracowników (art. $104 \S 2$ k.p. oraz art. $104^{1} \S 1$ pkt 5 k.p.). Natomiast w sytuacji, gdy pracodawca nie ma obowiązku ustalenia regulaminu pracy, informuje pisemnie pracownika o miejscu, terminie i czasie wypłaty wynagrodzenia w ciągu 7 dni od zawarcia umowy (art. $29 \S 3$ pkt 5 k.p.). Jeśli termin wypłaty wynagrodzenia pomimo wszystko nie został określony, wówczas stosuje się art. 455 k.c. (w zw. z art. 300 k.p.). Na tej podstawie

\footnotetext{
${ }^{25}$ Wyrok SN z dnia 7 maja 2008 r., II PK 331/07, OSNP 2009, nr 17-18, poz. 230.

${ }^{26}$ Wyrok SN z dnia 8 sierpnia 2006 r., I PK 54/06, OSNP 2007, nr 15-16, poz. 219.

${ }^{27}$ A. Sobczyk, Rozwiazanie..., s. 104.
} 
można przyjąć, że wypłata powinna nastąpić nie później niż w ostatnim dniu okresu obliczeniowego, a jeżeli taki nie został wprowadzony, to $\mathrm{w}$ ostatnim dniu miesiąca kalendarzowego ${ }^{28}$. Ponadto dopuszczalne jest przesunięcie terminu wypłaty wynagrodzenia, o czym stanowi art. 852 k.p. Zgodnie $\mathrm{z}$ tym przepisem, wynagrodzenie za pracę płatne raz w miesiącu wypłaca się z dołu, niezwłocznie po ustaleniu pełnej wysokości, nie później jednak niż w ciągu pierwszych 10 dni następnego miesiąca kalendarzowego. Zdaniem U. Torbus należy przyjąć, że termin na rozwiązanie umowy powinien być liczony od tego dnia ${ }^{29}$.

Co więcej, zdaniem Sądu Najwyższego możliwe jest przyjęcie, że termin 1 miesiąca wynikający $\mathrm{z}$ art. 52 $\$ 2$ k.p. jest zachowany, gdy pracownik składa oświadczenie o rozwiązaniu umowy $\mathrm{w}$ ciągu miesiąca od dnia ostatniego naruszenia obowiązku przez pracodawcę $^{30}$. Podkreślenia wymaga fakt, iż miesięczny termin na rozwiązanie umowy ma charakter zawity, co oznacza, że po upływie miesiąca pracownik traci prawo do rozwiązania umowy o pracę właśnie w tym trybie, czyli bez wypowiedzenia. W tym przypadku rozwiązanie umowy przez pracownika dokonane po upływie miesięcznego terminu będzie wadliwe. Złożenie oświadczenia woli o rozwiązaniu umowy przez pracownika będzie jednak skuteczne, co w konsekwencji doprowadzi do rozwiązania umowy o pracę.

Rozwiązanie umowy o pracę bez wypowiedzenia jest czynnością jednostronną, której skutkiem jest ustanie stosunku pracy w chwili, w której oświadczenie woli dotarło do adresata W sposób umożliwiający zapoznanie się z jego treścią. W przypadku zakończenia umowy przez pracownika oświadczenie woli powinno dotrzeć do osoby, która dokonuje czynności w sprawach z zakresu prawa pracy (art. $3^{1}$ k.p.). Zdaniem Sądu Najwyższego pracownik może rozwiązać umowę o pracę bez wypowiedzenia $\mathrm{z}$ powodu ciężkiego naruszenia przez pracodawcę jego obowiązków, działając przez pełnomocnika. Czynność ta wywołuje skutek rozwiązujący, choćby została dokonana bez umocowania lub z przekroczeniem jego zakresu, jeżeli pełnomocnik działał zgodnie $\mathrm{z}$ wolą pracownika lub ten potwierdził jej dokonanie ${ }^{31}$. Nie ma tu zastosowania przepis art. 104 k.c. ${ }^{32}$.

Ponadto treść art. $55 \$ 1^{1}$ k.p. wskazuje, że pracownik może rozwiązać bez wypowiedzenia umowę każdego rodzaju. W literaturze podkreśla się, że możliwość rozwiązania umowy o pracę na zasadach art. 55 k.p. nie jest wyłączona w razie upadłości

\footnotetext{
28 Ł. Pisarczyk, Obowiązek prawidłowej i terminowej wypłaty wynagrodzenia, „Praca i Zabezpieczenie Społeczne" 2002, nr 10, s. 32.

${ }^{29}$ U. Torbus, Glosa..., s. 67-78.

${ }^{30}$ Wyrok SN z dnia 24 października 2013 r., II PK 25/13, LEX nr 1413153.

${ }^{31}$ Wyrok SN z dnia 16 stycznia 2009 r., I PK 127/09, OSNP 2010, nr 15-16, poz. 183.

${ }^{32}$ Ustawa dnia 23 kwietnia 1964 r. - Kodeks cywilny (tekst jedn.: Dz. U. z 2014 r. poz. 121 ze zm.).
} 
pracodawcy, niezależnie od tego, czy jest to upadłość z możliwością zawarcia układu czy też upadłość połączona z likwidacją majątku dłużnika ${ }^{33}$.

Zgodnie z art. 55 §2 k.p., pracownik powinien zachować formę pisemną oraz wskazać przyczynę uzasadniającą rozwiązanie umowy o pracę bez wypowiedzenia. Ustne oświadczenie woli pracownika również wywołuje skutek w postaci rozwiązania umowy o pracę. W świetle orzecznictwa pracownik może wskazać kilka przyczyn rozwiązania umowy o pracę bez wypowiedzenia ze względu na ciężkie naruszenie podstawowych obowiązków pracodawcy, zaś rozwiązanie stosunku pracy jest uzasadnione, gdy choć jedna ze wskazanych przyczyn była usprawiedliwiona ${ }^{34}$. Z kolei w sytuacji rozwiązania przez pracownika umowy o pracę, gdy pracodawca dopuścił się ciężkiego naruszenia podstawowych obowiązków wobec pracownika, istotne jest rzeczywiste ciężkie naruszenie przez pracodawcę podstawowych obowiązków pracownika, a nie fakt powołania się na nie w piśmie rozwiązującym umowę o pracę $^{35}$.

Poza możliwościami przewidzianymi w art. 55 k.p. pracownik może rozwiązać umowę o pracę bez wypowiedzenia za siedmiodniowym uprzedzeniem na mocy art. $23^{1} \S 4$ k.p. oraz za trzydniowym uprzedzeniem na podstawie art. $48 \S 2$ k.p.; do rozwiązania tego jednak nie stosuje się bardziej szczegółowych reguł o charakterze formalnym, tj. formy pisemnej z uzasadnieniem, które wynikają właśnie z art. 55 §2 k.p., jak również w takich wypadkach nie przysługuje pracownikowi odszkodowanie od pracodawcy, od którego on odchodzi.

\section{Odszkodowanie należne pracownikowi}

Pracownikowi, który rozwiązał umowę o pracę bez wypowiedzenia $\mathrm{z}$ powodu ciężkiego naruszenia podstawowych obowiązków przez pracodawcę, przysługuje odszkodowanie w wysokości wynagrodzenia za okres wypowiedzenia, a jeżeli umowa o pracę została zawarta na czas określony lub na czas wykonania określonej pracy - w wysokości wynagrodzenia za okres 2 tygodni (art. $55 \S 1^{1}$ k.p.). Wówczas pracownikowi przysługuje odszkodowanie w wysokości wynagrodzenia za okres wypowiedzenia. W sytuacji rozwiązania przez pracownika umowy o pracę $\mathrm{z}$ powodu ciężkiego naruszenia podstawowych obowiązków przez pracodawcę pracownikowi przysługuje odszkodowanie $\mathrm{z}$ mocy prawa wprost wynikające z ustawy. Oznacza to, że oświadczenie woli pracownika wywołuje zamierzony

\footnotetext{
${ }^{33}$ M. Nowak, Rozwiąanie niezwłoczne umowy o prace przez pracownika $w$ razie upadłości pracodawcy, w: Prawo pracy, red. G. Uścińska, Warszawa 2013, s. 319.

${ }^{34}$ Wyrok SN z dnia 10 kwietnia 2008 r., III PK 88/07, Legalis nr 316350

${ }^{35}$ Wyrok SA w Gdańsku z dnia 28 lutego 2013 r., III AUa 1494/12, Legalis nr 755567.
} 
skutek prawny powodujący rozwiązanie umowy o pracę i wobec tego pracodawca nie może domagać się od pracownika, by ten powrócił do pracy. Pracodawca może jednak wystąpić z roszczeniem odszkodowawczym. Odszkodowanie takie może zostać zasądzone, gdy rozwiązanie umowy o pracę było nieuzasadnione ${ }^{36}$. W świetle orzecznictwa wysokość odszkodowania przysługującego pracownikowi na podstawie art. $55 \S 1^{1}$ k.p. jest niezależna od czasu, jaki miał upłynąć od chwili rozwiązania umowy o pracę w wyniku wcześniej dokonanego przez niego wypowiedzenia ${ }^{37}$. Odszkodowanie to nie jest uzależnione od rozmiaru poniesionej przez pracownika szkody. Do odszkodowania tego nie stosuje się art. 60 k.p., zaś art. 55 k.p. nie odsyła do art. 60 k.p. Zatem brak jest ustawowych podstaw do pozbawienia pracownika lub ograniczenia jego ustawowych uprawnień odszkodowawczych z tej przyczyny, że rozwiązanie stosunku pracy bez wypowiedzenia $\mathrm{z}$ winy pracodawcy nastąpiło $\mathrm{w}$ trakcie biegu okresu wypowiedzenia umowy o pracę dokonanego uprzednio przez pracodawcę.

Z wyroku Sądu Apelacyjnego z dnia 31 marca 2006 r. wynika, że odszkodowanie przysługuje pracownikowi bez względu na moment rozwiązania umowy, w tym także w przypadku jej rozwiązania w okresie wypowiedzenia ${ }^{38}$. Co do wysokości odszkodowania, nie ulega ono zmniejszeniu do faktycznego okresu, jaki pozostał do końca stosunku pracy ${ }^{39}$. Na gruncie art. $55 \S 1^{1}$ k.p. pojawia się wątpliwość, czy pracodawca, w przypadku rozwiązania stosunku pracy bez wypowiedzenia przez pracownika, może wstrzymać decyzję o wypłacie odszkodowania. Zdaniem A. Sobczyka, twierdzenie to jest uzasadnione. Mianowicie, z treści tego przepisu wynika, iż odszkodowanie przysługuje pracownikowi w sytuacji, gdy pracodawca dopuścił się ciężkiego naruszenia podstawowych obowiązków wobec pracownika. Ocena ciężkiego naruszenia obowiązków przez pracownika nie jest wiążąca dla pracodawcy, czyli nie musi jej uznać za słuszną ${ }^{40}$. W sytuacji, gdy pracodawca nie wypłaci odszkodowania, wówczas pracownik może dochodzić odszkodowania na drodze sądowej. Ponadto, pracodawca może również zakwestionować wskazane przez pracownika przyczyny rozwiązania stosunku pracy w procesie o odszkodowanie przewidziane $\mathrm{w}$ art. $61^{1}$ lub art. $61^{2}$ k.p., zaś w przypadku wstrzymania się z wypłatą odszkodowania przewidzianego w art. $55 \S^{1}$ k.p. zdanie drugie - także w procesie wytoczonym przez pracownika o to odszkodowanie. Gdy odszkodowanie zostało wypłacone, a rozwiązanie umowy okazało się

\footnotetext{
${ }^{36}$ J. Iwulski, W. Sanetra, Kodeks pracy. Komentarz, Warszawa 2013, s. 387.

${ }^{37}$ Wyrok SN z dnia 23 sierpnia 2005 r., I PK 20/05, OSNP 2006, nr 13-14, poz. 200.

${ }^{38}$ III APa 90/05, LEX nr 217087.

${ }^{39}$ Wyrok SN z dnia 23 sierpnia 2005 r., I PK 20/05, OSNP 2006, nr 13-14 poz. 200.

${ }^{40}$ A. Sobczyk, Rozwiązanie..., s. 105.
} 
bezzasadne, zastosowanie znajdą przepisy kodeksu cywilnego ${ }^{41}$ o świadczeniu nienależnym (art. 410 i nast. k.c. w zw. z art. 300 k.p.). Ponadto, w sytuacji gdy pracodawca odmawia wypłaty odszkodowania, pracownik może go dochodzić przed sądem pracy. Wówczas ciąży na nim obowiązek wykazania, że pracodawca ciężko naruszył wobec niego podstawowe obowiązki ${ }^{42}$.

Wysokość odszkodowania z art. $55 \S 1^{1}$ k.p. oblicza się według reguł obowiązujących przy ustalaniu ekwiwalentu pieniężnego za urlop (\$2 ust. 1 pkt 3 rozporządzenia Ministra Pracy i Polityki Socjalnej z dnia 29 maja 1996 r. ${ }^{43}$ ). Z kolei reguły obliczania ekwiwalentu pieniężnego za urlop wypoczynkowy (z pewnymi modyfikacjami) ustala się, stosując zasady obowiązujące przy obliczaniu wynagrodzenia urlopowego na podstawie §14-19 rozporządzenia Ministra Pracy i Polityki Socjalnej z dnia 8 stycznia 1997 r. $^{44}$.

\section{Skutki prawne rozwiązania umowy o pracę przez pracownika}

$\mathrm{Z}$ artykułu $55 \S 3$ k.p. wynika, iż w sytuacji rozwiązania umowy o pracę z przyczyn określonych w $\S 1 \mathrm{i} \S 1^{1} \mathrm{k} . p$., stosuje się przepisy prawa odpowiednie dla rozwiązania umowy o pracę przez pracodawcę za wypowiedzeniem. Jest to swego rodzaju fikcja prawna. W konsekwencji tego, pracownik może nabyć uprawnienia, które według konkretnych uregulowań prawa wewnętrznego należne są pracownikowi zwalnianemu przez pracodawcę ${ }^{45}$. Należy podkreślić, iż rozwiązanie umowy o pracę bez wypowiedzenia przez pracownika z winy pracodawcy nie może być uznane za ustanie stosunku pracy w związku z przejściem na emeryturę (art. $92^{1} \S 1$ k.p.), co skutkuje tym, że pracownikowi nie przysługuje wówczas odprawa pieniężna, nawet przed rozwiązaniem stosunku pracy ${ }^{46}$.

\section{Uwagi końcowe}

Kodeks pracy enumeratywnie wylicza przesłanki będące podstawą rozwiązania stosunku pracy przez pracownika bez wypowiedzenia. Artykuł $55 \S 1^{1}$ k.p. wymienia ciężkie naruszenie obowiązków przez pracodawcę jako podstawę rozwiązania stosunku pracy przez pracownika

\footnotetext{
${ }^{41}$ Dz. U. z 2014 r., poz. 827.

${ }^{42}$ E. Maniewska, K. Jaśkowski, Kodeks pracy Tom I, Komentarz LEX, Warszawa 2014, s. 280.

${ }^{43}$ Rozporządzenie Ministra Pracy i Polityki Socjalnej z dnia 29 maja 1996 r. w sprawie ustalania sposobu wynagrodzenia w okresie wykonywania pracy oraz wynagrodzenia stanowiącego podstawę obliczania odszkodowań, odpraw, dodatków wyrównawczych do wynagrodzenia oraz innych należności przewidzianych w Kodeksie pracy (Dz.U. Nr 68, poz. 289 ze zm.).

${ }^{44}$ Rozporządzenie Ministra Pracy i Polityki Socjalnej z dnia 8 stycznia 1997 r. w sprawie szczegółowych zasad udzielania urlopu wypoczynkowego, ustalania i wypłacania wynagrodzenia za czas urlopu oraz ekwiwalentu pieniężnego za urlop (Dz.U. Nr 2, poz. 14 ze zm.).

${ }^{45}$ A. Sobczyk, Rozwiazanie..., s. 106.

${ }^{46}$ Wyrok SN z dnia 16 listopada 2000 r., I PKN 81/2000, OSNAPiUS 2002, nr 11, poz. 265.
} 
bez wypowiedzenia. Doktryna wyraża dwa przeciwstawne poglądy co do ciężkiego naruszenia obowiązków pracodawcy. Pierwszy z nich zakłada, że do ciężkiego naruszenia niezbędne jest pojawienie się winy pracodawcy, drugi natomiast nie uwzględnia winy pracodawcy. Problemem spornym w doktrynie jest właśnie kwestia winy pracodawcy w przypadku ciężkiego naruszenia przez niego obowiązków. Moim zdaniem, skoro pracodawca w jakikolwiek sposób narusza podstawowe obowiązki pracownika, to robi to świadomie, zaś tłumaczenie, iż nie znał prawa, bądź nie wiedział, iż narusza swój obowiązek, jest bezzasadne zgodnie z paremią łacińską ignorantia iuris nocet. Uważam, że w pierwszej kolejności należy rozstrzygnąć, czy pracodawca naruszył podstawowy obowiązek wobec pracownika, a dopiero potem ustalić, czy to naruszenie miało charakter ciężki. Niezależnie od przyczyny rozwiązania stosunku pracy przez pracownika bez wypowiedzenia przysługuje mu z tego tytułu odszkodowanie w wysokości wynagrodzenia za okres wypowiedzenia. Z drugiej strony odszkodowanie należy się pracodawcy, o ile nie udowodniono mu ciężkiego naruszenia jego podstawowych obowiązków wobec pracownika. Podkreślenia wymaga fakt, iż w przypadku ciężkiego naruszenia podstawowego obowiązku przez pracodawcę, którym jest zaniechanie wypłaty wynagrodzenia, pracownik ma prawo, a nie obowiązek do niezwłocznego rozwiązania umowy. Oznacza to, że pracownik nie musi rozwiązywać umowy obligatoryjnie w sytuacji, gdy pracodawca po raz pierwszy nie wypłacił mu wynagrodzenia. Warto także podkreślić, że miesięczny termin rozwiązania umowy przez pracownika z winy pracodawcy ma charakter zawity. Po upływie tego terminu rozwiązanie umowy przez pracownika w tym trybie będzie wadliwe, ale skuteczne i w konsekwencji doprowadzi do rozwiązania umowy o pracę.

\section{Bibliografia:}

\section{Literatura}

Dörre-Nowak D., Monitoring $w$ miejscu pracy a prawo do prywatności, „Praca i Zabezpieczenie Społeczne" 2004, nr 9

Góral Z., Kontrola pracownika a zasada ochrony jego godności i innych dóbr osobistych zagadnienia wybrane, w: Kontrola pracownika. Możliwości techniczne i dylematy prawne, red. Z. Góral, Warszawa 2010

Iwulski J., Sanetra W., Kodeks pracy. Komentarz, Warszawa 2013

Kodeks pracy. Komentarz, red. K.W. Baran, Warszawa 2012

Kodeks pracy. Komentarz, red. L. Florek, Warszawa 2005

Liszcz T., Ochrona prywatności pracownika w relacjach z pracodawca, „,Monitor Prawa Pracy” 2007, nr 1

Maniewska E., Jaśkowski K., Kodeks pracy. Komentarz, t. 1, Warszawa 2014

Musiała A., Niewyplacenie wynagrodzenia ciężkim naruszeniem podstawowych obowiazków pracodawcy, „Monitor Prawa Pracy” 2008, nr 4 
Nowak M., Rozwiazanie niezwłoczne umowy o prace przez pracownika $w$ razie upadłości pracodawcy, w: Prawo pracy, red. G. Uścińska, Warszawa 2013

Piankowski M., Niezwłoczne rozwiazanie stosunku pracy przez pracownika, w: Prawo pracy po zmianach, red. K. Rączka, Warszawa 1997

Pisarczyk Ł., Obowiazek prawidlowej i terminowej wypłaty wynagrodzenia, „Praca i Zabezpieczenie Społeczne" 2002, nr 10

Sanetra W., Kilka uwag o pojęciu odpowiedzialności w prawie pracy, „Praca i Zabezpieczenie Społeczne" 2007, nr 11

Sobczyk A., Rozwiazanie umowy o prace bez wypowiedzenia, Warszawa 2010

Torbus U., Glosa do wyroku SN z dnia 24 października 2013 r., II PK 25/13, GSP- Prz. Orz. 2014, nr 3

Wujczyk M., Prawo pracownika do ochrony prywatności, Warszawa 2012

\section{Orzecznictwo}

Wyrok SN z dnia 24 października 2013 r., II PK 25/13, LEX nr 1413153

Wyrok SN z dnia 27 lipca 2013 r., I PK 53/12, OSNP 2013, nr 15-16, poz. 173

Wyrok SN z dnia 8 października 2009 r., II PK 114/09, LEX nr 558297

Wyrok SN z dnia 23 września 2009 r., IV KK 66/09, LEX nr 524064

Wyrok SN z dnia 8 lipca 2009 r., I BP 5/09, OSNP 2011, nr 5-6, poz. 69

Wyrok SN z dnia 16 stycznia 2009 r., I PK 127/09, OSNP 2010, nr 15-16, poz. 183

Wyrok SN z dnia 7 maja 2008 r., II PK 331/07, OSNP 2009, nr 17-18, poz. 230

Wyrok SN z dnia 10 kwietnia 2008 r., III PK 88/07, Legalis nr 316350

Wyrok SN z dnia 6 marca 2008 r., II PK 185/07, OSNP 2009, z. 13-14, poz. 170

Wyrok SN z dnia 21 lutego 2008 r., II PK 171/07, OSNP 2009, nr 9-10, poz. 118

Wyrok SN z dnia 5 czerwca 2007 r., III PK 17/07, LEX nr 551138

Wyrok SN z dnia 7 grudnia 2006 r., I PK 123/06, OSNP 2008, nr 1-2, poz. 14

Wyrok SN z dnia 8 sierpnia 2006 r., I PK 54/06, OSNP 2007, nr 15-16, poz. 219

Wyrok SN z dnia 23 sierpnia 2005 r., I PK 20/05, OSNP 2006, nr 13-14, poz. 200

Wyrok SN z dnia 5 lipca 2005 r., I PK 276/04, ,Wokanda” 2006, nr 2

Wyrok SN z dnia 16 listopada 2000 r., I PKN 81/2000, OSNAPiUS 2002, nr 11, poz. 265

Wyrok SN z dnia 4 kwietnia 2000 r., I PKN 516/99, OSNP 2001, z. 11, poz. 601

Wyrok SA w Gdańsku z dnia 28 lutego 2013 r., III AUa 1494/12, Legalis nr 755567

Wyrok SA w Katowicach z dnia 31 marca 2006 r.III APa 90/05, LEX nr 217087 